English Education Journal

UNNES http://journal.unnes.ac.id/sju/index.php/eej

\title{
Target Situation in Vocational High School Civil Engineering Students' Needs Analysis
}

\author{
Wigati Martina $^{1 凶}$, Puji Astuti $^{2}$, Dwi Anggani Linggar Bharati ${ }^{2}$ \\ ${ }^{1 .}$ SMK Negeri 7 Semarang, Indonesia \\ 2. Universitas Negeri Semarang
}

\begin{tabular}{l}
\hline Article Info \\
\hline Article History: \\
Recived 14 November \\
2020 \\
Accepted 27 January \\
2021 \\
Published 20 June \\
2021 \\
\hline Keywords: \\
Vocational high \\
school, needs analysis, \\
English for Specific \\
Purposes
\end{tabular}

\begin{abstract}
Needs analysis for vocational high school English course is important because English course for vocational high school is considered too general compared to the target situation that the students will need in their future career. This study aimed to analyse the students' teachers', alumni's, stakeholders', and expert's perceptions to explain the vocational high school civil engineering students' needs in their English course. This study used a qualitative case design by using open questionnaires and in-depth interviews as the methods of collecting data. The findings showed that the main goal of the English course was to prepare the students to face the needs of English in their target situation. The learning approach needed was a scientific approach by using inquiry or discovery learning. The students needed more learning source which involved the target situation and a course which considered their current English proficiency. Finally, the students needed a course set that represented the target situation and teachers who were not only experts in pedagogical competence but also ESP. The results of the study can be used by the education practitioners to help them design better course for vocational high school civil engineering students.
\end{abstract}

\footnotetext{
Correspondence Address:

J1. Simpang Lima, Mugassari, Kec. Semarang Sel., Kota Semarang, Jawa Tengah 50249

E-mail: wigatimartina@gmail.com
} 


\section{INTRODUCTION}

Vocational high school students in Indonesia right now are demanded to be more competitive. They must prepare the students to join the global society or else they will not be able to survive the global business and industries. Therefore, vocational high school students have to increase their competencies and skills to be compatible with the need in the work field. Not only technical skills, they also need other supporting skills. One of them is language skill. English is needed to keep up with the development of science and technology used in the work field. Therefore, mastering English is very important for vocational high school students to support their future career (Ronaldo, 2016).

Government has designed an English curriculum to support the vocational high school students to prepare themselves for their future career. However, the prior researches suggested that the current English curriculum needs evaluation. Evaluating curriculum can be done through need analysis (Astuti, 2009). As vocational high school students will enter specific areas in the work field, they need specific English course to support their future career. It is in line with law No 20/2003 states the aim of secondary vocational education is to prepare students for work in a particular field.

There are many indications that English teaching and learning in vocational high school right now does not comply with the need of the students as professional worker candidates. Not only that the curriculum was too general, the materials and assessment were problematic (Arifin et al, 2017). Cahyati et al (2014) stated in their research that the books used by SMK published by the Ministry of Education do not have specific purposes since they only focus on general reading and writing skills.

English for Specific Purposes (ESP) has been popular since 1960s. The need of ESP is getting higher in accordance with the development of business fields. Therefore,
ESP is used in many colleges and universities. However, it is not only college and university students who need to acquire English according to the work field they are going to face after they graduate. Vocational high school students do too (Estiningkrida \& Munir, 2015).

The previous studies in vocational high school area suggested more investigation on the need analysis. The investigations of the needs were conducted by Alsamadani (2018), Bedoya et al (2015), Hossain (2013), Indrasari (2016), Otilia (2015), Wahyono \& Puspitasari (2016) and Liao, Hsu, Lee and Yang (2017). Those studies were aimed to figure out the students' needs in various area such as tourism department, engineering department, hospitality department, teacher training and various skills like reading, writing, listening and three of them combined. However, there are still limited data about the needs of vocational high school which consists of many departments (Albakrawi, 2013). Civil engineering is chosen because it is one of many departments of vocational high school which most likely require English skills in the work field. Hence, unlike tourism department, construction engineering department has few researches on it. The multinational construction projects require the people involved to be able to communicate in English.

The study aims to analyse the students', teachers', stakeholders', alumni's and experts' perception in order to explain the needs of vocational high school civil engineering students in their English course. The needs were investigated by involving the target situation and the parties involved. It is important to be explored to understand the true goals of the English teaching and learning process since the current English course for vocational high school students is a general English course which does not consider the target situation. 


\section{METHOD}

The study used a qualitative case study design to investigate the vocational high school civil engineering students' needs in their English course. Qualitative research tends to find the data by observing the context directly and followed by researcher's interpretation (Bharati \& Lestari, 2018). This study focused on investigating the perception of the students, teachers, stakeholders, alumni and expert about the students' needs. There are three aspects which need to be observed as proposed by Hutchinson and Waters (1991). They are necessity, wish and lack. Every aspect involves different participants depending on the parties which concern.

Based on the three aspects, the needs analysis focused on investigating the goals, the learning approach and methods, the learning sources including media and material, the learners' background and characteristics and lastly, the setting.

This study involved 97 students of civil engineering department of SMK Negeri 7 Semarang, three EFL teachers of the same school, 55 alumni of the same department, two stakeholders and one expert. The students were from three different classes. The classes were taught by the three different EFL teachers involved in the study. The alumni were from various years of graduation and work in different companies and civil engineering areas. The stakeholders were a site manager and a project manager of two construction companies which almost every year has the school graduates recruited. Lastly, the expert was a doctor of civil engineering who was teaching at a university and became an assessor for vocational high school students of related department in Central Java.

Methods of data collection in this research were questionnaires and interviews. Questionnaires was used for the students and the alumni due to the big number of the participants. In-depth interview was used for the teachers, stakeholders and expert. This study involved semi open questionnaires which was distributed using Google Form and in-depth interview guidance. The data was documented in form of charts, notes and recordings.

\section{RESULTS AND DISCUSSION}

\section{Necessity Required by the Target Situation}

Necessity deals with the required competencies in the real world use. To obtain reliable and trustworthy data, this research involved three different parties namely alumni, stakeholders and expert.

\section{The Language Skills}

There are four main language skills in English learning namely listening, reading, speaking and writing. In civil engineering area, both stakeholders and the expert agreed that reading should be the priority. While the opinion of the alumni can be seen below.

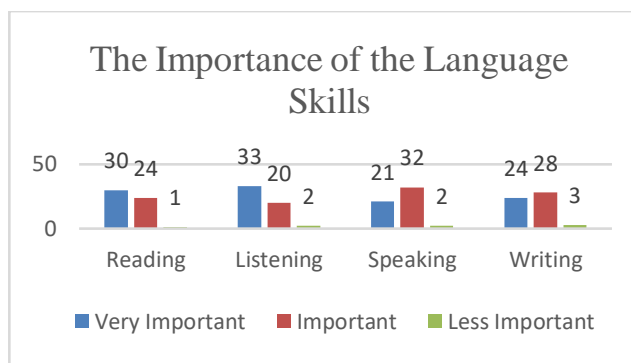

Figure 1. The Alumni's Importance of the Language Skills

Alumni, stakeholders and experts agreed that those skills were almost in equal importance. Alumni and the second stakeholder believed that listening was the secondly important. The stakeholder stated that in fact, when there was a foreigner visits as instructor, assessors or other, listening skill was very needed. He said that most workers were bad at listening because they did not use to listening to native speakers. He added that it would be very useful if the workers had good listening skill. They did use the service of a translator but sometimes the technical terms were slipped and it would be better if the audience knew both the language and the knowledge. 
All participants agree that writing skill is important as well. It is useful when they write reports. Even though the writing should not be the complicated ones, they still need to fill the forms and write the technical terms in English. Just like writing skill, speaking skill is also important but not frequently used by the workers. The participants argued that there is very little chance for the workers from vocational high school would likely use English for spoken communication. They said that as long as the workers acquire passive English, that would be enough to support their job.

Besides the four skills, the participants added some other skills. Some alumni added grammar skill. It is approved by the stakeholders. They said that grammar skill is important to support the four skills. Vocabulary learning is also suggested to be improved.

It can be summed up that reading skill is the most needed skill. However, other skills namely writing, listening and speaking are still needed in some situation. Grammar and vocabulary are also needed to support the four skills.

\section{The Language Use Area}

English is used for different purposes and occasions in the work place. The finding shows the area and occasion where and how English is used. The opinion of the alumni is presented below.

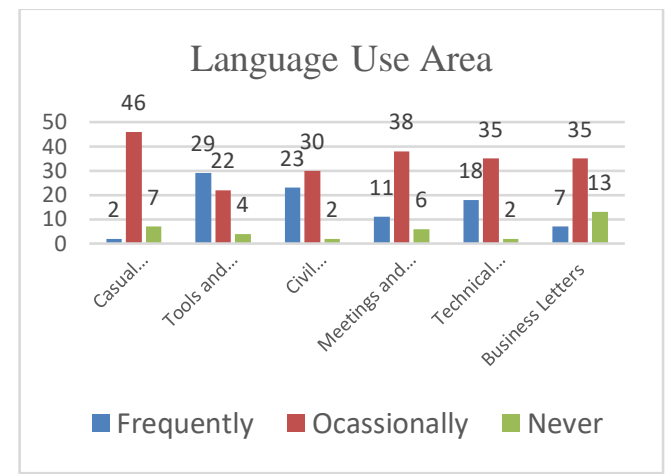

Figure 2. The Alumni's Language Use Area

The findings show that English is mostly used in the tools and instruments, civil engineering documents and technical terms in the work field. The participants explained that most tools and instruments are made in other countries. The explanations and manuals are displayed in the language of the origin and English. The findings also show that English is used quite a lot in the documents. The expert and the stakeholders agreed that documents are where the workers need English the most. They explained that the documents such as site plan, engineering pictures, technical drawings, etc. are what they face daily. According to the alumni, English is used quite a lot in the working site. The expert and the stakeholders hold the same opinion because things, processes, technology, materials and many stuffs the worker meet in the working site use English. Not knowing the correct terms of things in the working site may create problems for the working process because the terms they know must be standard and synchronized with the written documents.

English is used occasionally for casual conversation, formal occasion and letters. They said that there was only little chance for the worker to use English for daily conversation. Once in a while they probably have to meet face to face with foreigners and they need to do casual conversation for socialization. Sometimes, the vocational high school graduates still participate in meetings or seminars as audience where sometimes the presenter uses English especially if the project is join operation project. They at least need to understand the content of the material presented in the meetings or seminars. Writing letter is English is quite rare unless in the workers need to make request letter, invoice, or report in certain situation.

In the open essay, some alumni wrote that they would likely use English in some other situations. Some of them wrote that they need English when surfing in the internet or reading journal articles to get information about their job. It is approved by the second stakeholder by saying that internet is an important source of reference and it is mostly presented in English. Another alumnus wrote that sometimes he gets project 
which the owner is foreigner and he needs to be able to communicate in English.

Preferred Topics and Materials

These findings were obtained by presenting the current curriculum content to the participants and proposing some potential topics and materials about civil engineering. The opinion of the alumni is summed up below.

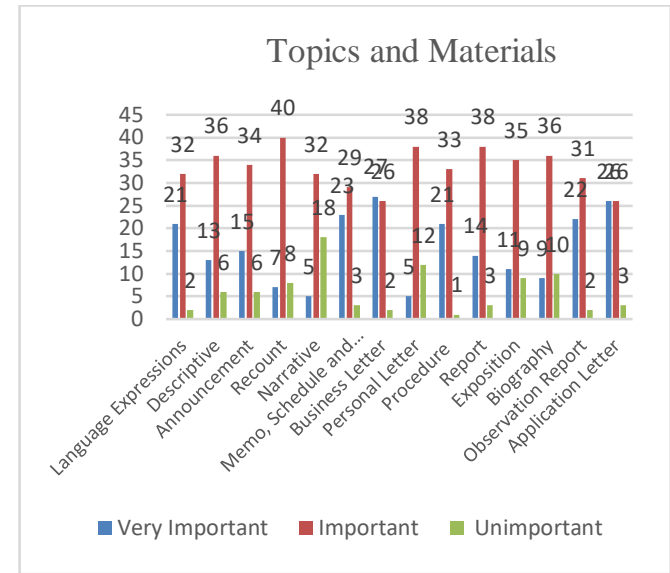

Figure 3. The Alumni's Preferred Topics and Materials

The first is about language expressions. In the curriculum, there are several standard competencies about language expressions such as introduction, congratulating, giving direction, offering, showing opinion and many more. The expert and the stakeholders had the same opinion that beside those expressions had been learned in junior high school, using expressions for communication can be learnt independently and the capability of using them depend on each individual's effort instead of the lesson at school.

Some texts mandated by the curriculum are considered needed and some others are less important. Some texts which are considered important by most of the alumni, the expert and the stakeholders are announcement, memo, schedule, signs, business letters, manuals and procedures, action report and application letters.

There are several materials I proposed based on earlier observation on the field. They are properties and materials, tools and instruments, trend, innovation and technology, safety in the workplace and technical vocabulary. The opinion of the alumni can be seen on the chart below.

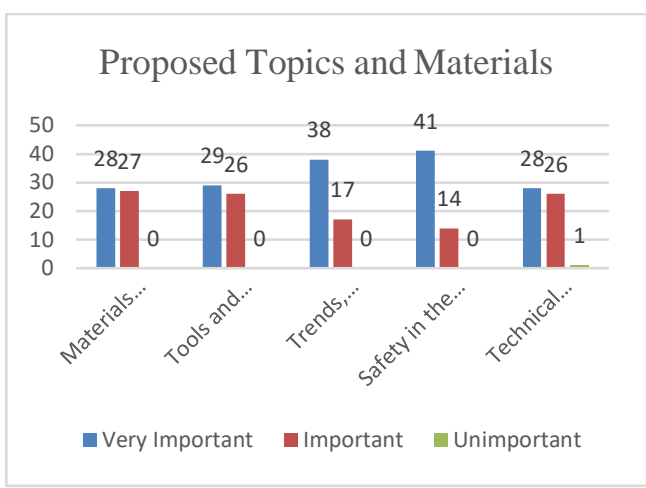

Figure 4. The Alumni's Proposed Topics and Materials

All participants agreed that topic about properties and materials and tools and instruments are important. The expert and the stakeholders claimed that workers need to know a lot about those topics which mostly use terms in English. Topic about trend, innovation and technology is also considered important by all participants. The expert stated that this topic is useful for enrichment but it doesn't need to be in detail. The stakeholders had slightly different opinion that this topic is quite useful in the workplace since technology always develops. Topic about safety in the workplace is considered important by the alumni and the stakeholders while the expert believed that this safety in the workplace is not really needed to be learned in English because usually it uses pictures that everyone can understand.

\section{Preferred Instructional Procedures}

The instructional procedures here are the common procedures used by the teachers in the classroom and those that are mandated by the curriculum based on the approach and learning models. The summary of the alumni's opinion is presented on the chart below. 


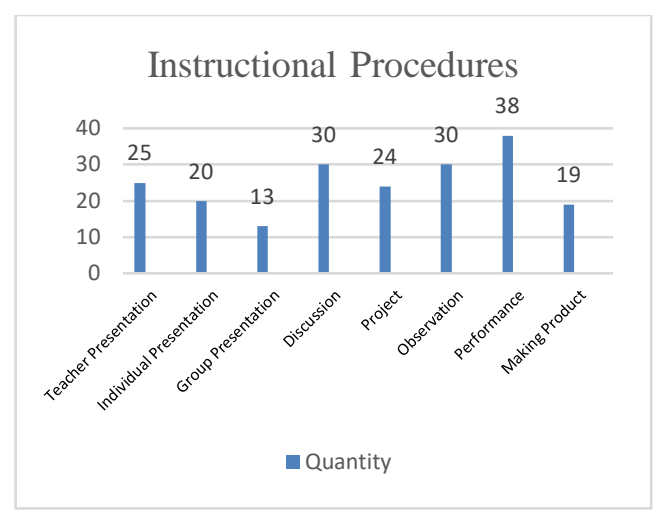

Figure 5. The Alumni's Preferred Instructional Procedures

$45.5 \%$ of the alumni agreed on teacher presentation, $36.4 \%$ on individual presentation, $26.3 \%$ on group presentation, $54.5 \%$ on discussion, $43.6 \%$ on project, $54.4 \%$ on observation, $69.3 \%$ performance, $34.5 \%$ on making product. The expert and the stakeholders claimed that they didn't really understand about instructional procedures in teaching language. However, they gave their opinion on some common techniques used. The expert believed that teacher presentation might be needed for difficult materials. Discussion and presentation are good to motivate the students develop themselves. She also stated that observing realia and inviting guest teacher is good for giving experience. The stakeholders had similar opinion with the stakeholders with additional point about using internet in the teachinglearning process.

\section{Preferred Assessment Procedures}

There are several assessment procedures I suggested in this study based on the common assessment procedures used by the teachers and those which are suggested by the curriculum. The opinion of the alumni can be seen on the chart below.

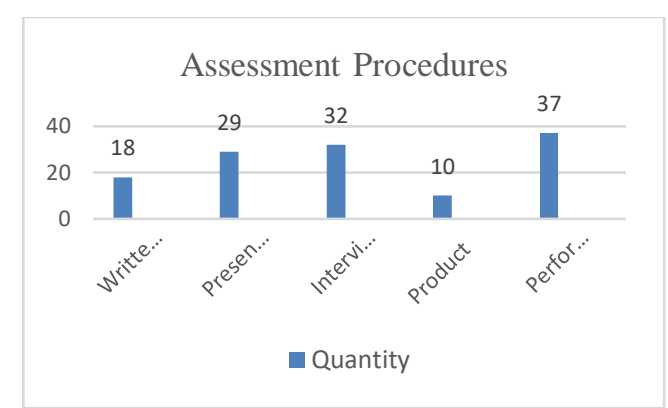

Figure 6. The Alumni's Preferred Assessment Procedures

Among many assessment procedures, practice and performance is the most supported by the alumni which is $67.3 \%$. Interview comes the second with $58.2 \%$ supporters, presentation gets $52.7 \%$, written test gets $32.7 \%$ and making product gets $18.2 \%$. The expert considered written test suitable to assess knowledge and presentation to assess skills. She added that presentation can also train the students' skills in using English. The stakeholders suggested interview and listening test besides written test. They believed that listening must be put into consideration because it is important yet the students have weak skill.

\section{Wants of the Learners}

Wants deals with the wish of the learners. 97 students were involved to gain this information. They were three classes of civil engineering program. Two classes were eleventh grade and the other one was tenth grade. The students gave their responses by completing questionnaires.

\section{The Importance of Learning English}

All students believed that English is important both for working and for general need. However, some students have low interest in English. The summary is presented on the chart below. 


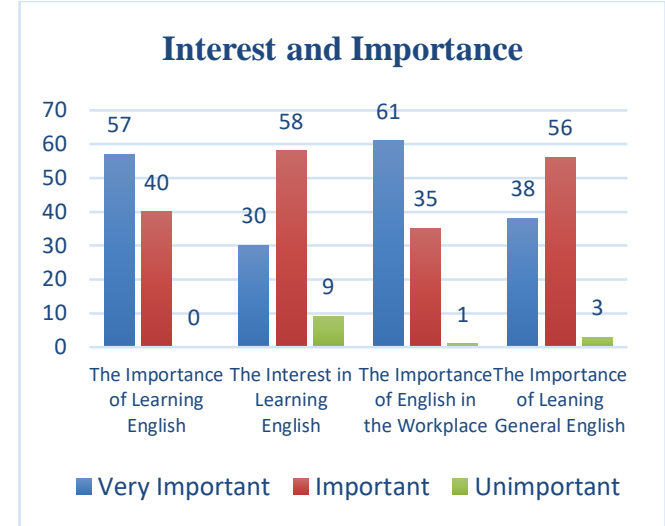

Figure 7. The Students' Interest and the Importance of English

\section{Goals}

The finding shows three major goals. $57.7 \%$ of the students stated that they learn English for their future career. $46.4 \%$ believed that they need to learn English for the sake of examination and $24.7 \%$ said that it is for communication. Some students also wrote that it is for entertainment such as reading book, watching movie and playing games.

Preferred Skills

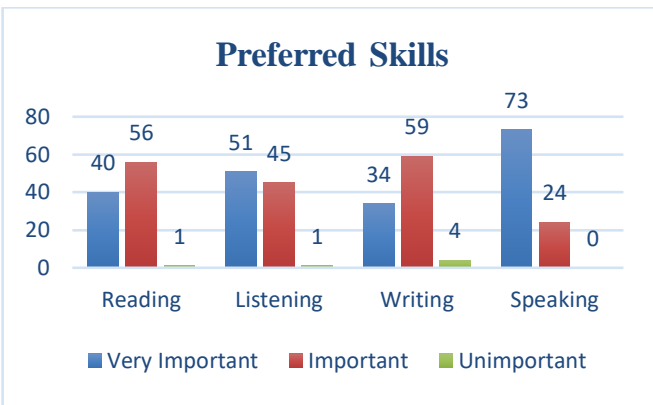

Figure 8. The Students' Preferred Skills

Among four skills, the students put their priority on speaking which was $75.3 \%$. The second priority is listening with $52.6 \%$ believed that it is very important. The third rank goes to reading skill with $41.2 \%$ stated that it is very important. Writing becomes the last priority with $35.1 \%$ believed that it is very important. Some students added comments in the open essay. Some wrote grammar, vocabulary and translating in the open essay section.

\section{Preferred Topics and Materials}

According to the materials mandated by the curriculum, the students had set their priority based on the importance. There are several texts they should learn. The texts which were considered either very important or important are application letter, action report, business letters, procedure and manual, memo, schedule and signs and announcement. The other texts which are considered less important are biography, descriptive, narrative, recount, exposition, report and exposition. The detail of the finding can be seen below.

The next materials are expressions. Some expressions which are considered important by the students are introduction, offering, asking and giving opinion, asking and giving direction and suggestion. The other expressions which are considered less important are congratulating, showing intention, and talking on the phone.

The students also gave their opinion on the proposed topics. The students gave positive responds either very important or important towards the following topics; materials and properties, tools and instruments, trend, innovation and technology, safety in the workplace and specific vocabulary. In the open essay, some students wrote their opinion about other important topics. They are English used in the construction drawings and presentation and public speaking. The detail of the finding can be seen below.

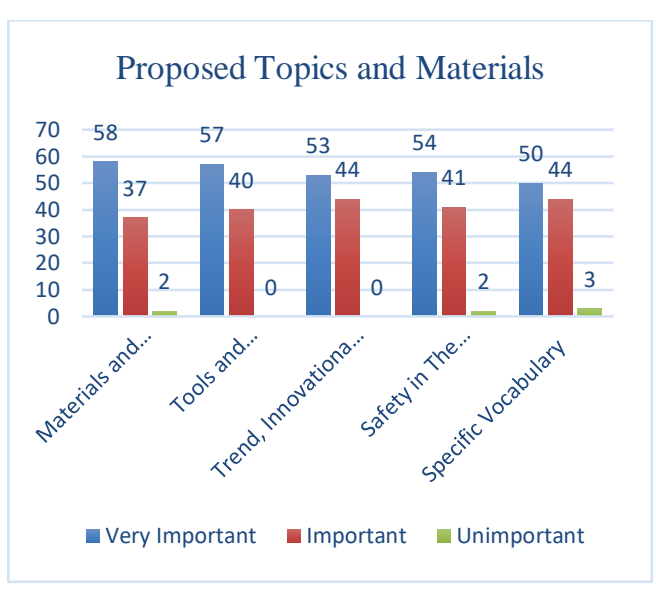

Figure 9. The Students' Proposed Topics and Materials 


\section{Preferred Instructional Procedures}

As much as $85.6 \%$ of the students picked teacher's presentation as one of the preferred instructional procedures. The next most favourite procedure is practice and performance which got 79 supporters or $81.4 \%$ of the students. Discussion is the next, chosen by $68 \%$ of the students. Observing realia is the next preferred which got $65 \%$ support. Making project got $48.5 \%$ supports as well as making product. The least popular are group presentation which got $36.1 \%$ support and individual presentation which got $24.7 \%$ support.

\section{Preferred Assessment Procedures}

Most of the students prefer practice and performance for the assessment procedures. It got $75.3 \%$ support. The secondly preferred is written test. Presentation is the next which got $46.4 \%$ support. Interview gets $36.1 \%$ support and product gets $30.9 \%$ support. Additionally, one student mentioned speaking test and another student mentioned listening test.

\section{Lacks of the Learners}

Information about lack or present ability were taken from two different participants, the students and the teachers. The following is the summary of the students' responses about their assessment on their present ability.

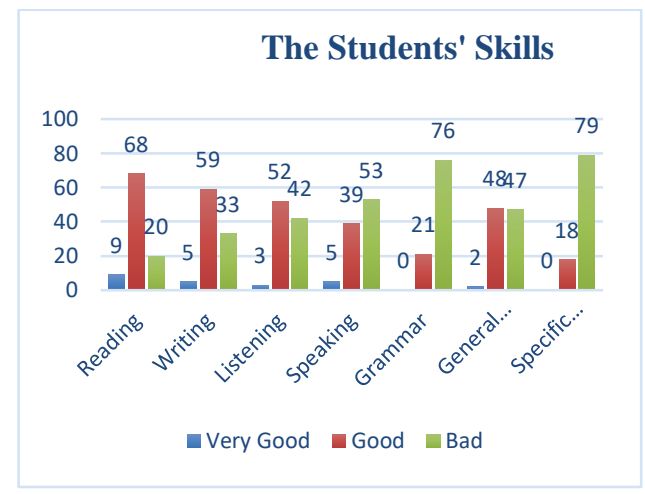

Figure 10. The Students' Skills

The students are quite confident with their reading ability. $9.3 \%$ of the students stated that they have a very good reading skill, $70.1 \%$ stated that they have a good reading skill. More than half of the students are confident with their ability in writing which is $60.8 \%$. Only five students are confident that they have a very good ability in writing. 42 of 97 students believed that they are weak at listening. Most of the students are not confident with their speaking ability which is $54.6 \%$. $78.4 \%$ of the students admit that they have bad grammatical competence. Most students believed that they are bad at specific vocabulary. It is as much as $81.4 \%$ of them.

The teachers stated that speaking was the most difficult skill for the students. the students they taught were weak in speaking. They needed a lot of stimuli to make them speak. Moreover, they had very limited vocabulary and grammatical competence and also weak pronunciation. They said that the teacher had to ask question or call the students first before they start speaking. Writing was the second weakest skill. The reason was the same that the students were lack of vocabulary and grammatical competence. Their listening skill was better than the early two. They said that the students can do listening task better than writing task. It is because the students were quite good in gasping meaning of the listening materials. Among all skills, reading was the strongest. The teachers said that the students did not get significant difficulty in reading comprehension. However, they added that the texts were common text and had common vocabulary. In fact, the teacher's opinion about the students' vocabulary and grammatical competence was in accordance with the students' opinion. They had low ability in grammar and in vocabulary especially technical vocabulary.

\section{Needs Evaluation Results}

After obtaining the aspects of needs analysis namely necessity, wants and lack, it is then continued to assess the data in order to decide the needs of the learners. The data were analysed by classifying which of those were mutually inclusive based on the goals, the learning approach and methods, the learning sources including media and 
material, the learners background and characteristics and the setting.

\section{Goals from the Target Situation}

The expert believed that the English lesson in vocational high school should be prepared to support their job. The stakeholders and the alumni believed that the goal of English lesson is to support their future job and for self-development in their area. However, succeeding in National Examination is one of the students' goals besides for communication and to support their career.

Alumni, expert and stakeholders are those who have experienced the needs of English in the real-world use as the ones who work in civil engineering area compared to the students. Their opinion about the goals of learning English is more legitimate than the students'. Therefore, the truly goal of vocational high school students should be to prepare them facing the needs in their future job. However, in fact, succeeding at National Examination is a demand. It is because National Examination is one of the considerations of their success in having the education. It can be seen as short-term goal even though the current system of National Examination is mutually exclusive with the true goal of English lesson for vocational high school. Dewi (2015) stated that the existence of National Examination switched the needs of the students from real world communication to an examination.

Communication is said to be the goal too by the students as they believed that they will need it in their casual communication. However, the alumni, the expert and the stakeholders confirmed that it was not prioritized. Communication in English doesn't happen very often in their target situation.

\section{Learning Approach and Methods}

The findings show that the alumni, expert and stakeholders, did not complain on the current learning approach and methodology. They agreed on what approach and methods mandated by the curriculum and trusted the teachers. They said that the authority had thought about the best approach and methods for teaching language. The students' wish also supported the current approach and method used in the classroom. It can be summed up that the learning approach they need is the current used approach, scientific approach. The methods are discovery and inquiry learning. The prioritized activities are performance, discussion, teacher's presentation and observation. The suggested activities are observing realia, listening activity and students' presentation. The prioritized assessments are test for assessing knowledge, performance for assessing skills. Additional assessment procedures are interview and presentation.

\section{Learning Source}

From four different parties who participated in this study, there are several materials which are mutually inclusive thus can be stated to be the materials needed by the students. The texts that are needed by the students are application letter, business letter, announcement, action report, procedure and memo, schedule and signs. These kinds of texts are considered to be familiarized by the students because in the practical level, they will likely meet them in the target situation. All language expressions mandated by the curriculum can be put in the supporting materials to help the students do casual conversation. According to the present ability of the students, grammar and vocabulary need to be prioritized as well. The proposed topics were all applauded by all parties. They are materials and properties, tools and instruments, trend, innovation and technology, safety in the workplace and specific vocabulary. The experts and stakeholders suggested specific theme for the texts, dialogs and vocabulary. Additional sources suggested are realia, occupation experts and real sites. To present those materials, they suggested electronic media such as projector, computer and smartphone beside classroom equipment.

\section{Learners' Background and Characteristics}

There are two focuses of the learners' background and characteristics. They are the 
present ability of the students and the language use area. The findings show that the students have low English proficiency and low in three skills which are listening, writing and speaking. Besides, individual ability of the students also need to be considered. From the language used area, the specific occupational topics should be considered in designing the English course.

Thus, it can be concluded that the learning process should embrace the proficiency of the students and the target situation needs of their occupation. Setting

Seeing the importance of English as stated in previous discussion, it is right that English lesson is set as compulsory lesson. The problem lies on the time allocation and the schedule. The teachers claimed that the time was lack compared to amount of the basic competencies. The time fitted the current basic competencies but was lack for occupation material and skills development. This claim was supported by the alumni's, expert and stakeholders' opinions. The block system schedule also created problem because the students did not get the same amount of the lesson each week. It hampered the teachers' plan. In conclusion, the English lesson there needs to be compulsory, more than three times forty-five minutes a week and in regular and routine schedule.

The second issue is about the teachers. Considering the needs in the target situation, the teachers should not only have language and pedagogical expertise but also occupational expertise. If the teachers are not the occupation practitioners, at least they need to be trained or certified to be teachers of English for specific purposes. This will guarantee that the teachers are credible enough to teach the vocational high school students.

The next issue is about the place. If tourism department students need to practice their English with real tourists and in a real tourism site, civil engineering students too need similar situation. The students need to learn with real objects, or at least with acceptable simulation of the real object. When the teaching-learning process is conducted in classroom, they will need media that support the simulation or the teachers can make use of their workshop.

\section{CONCLUSION}

This study aimed to analyze the students' teachers', alumni's, stakeholders', and expert's perceptions to explain the vocational high school civil engineering students' needs in their English course. The findings showed that the main goal of the English course is to prepare the students to face the needs of English in their target situation besides for communication and the short goal is to succeed in National Examination. The learning approach needed is the scientific approach by using inquiry or discovery learning. The student needs more learning source which involves the target situation and a course which considers their current English proficiency. Finally, the students need a course setting that represents the target situation and teachers who are not only experts in pedagogical competence but also ESP. The results of the study can be used by the education practitioners to help them design better courses for vocational high school civil engineering students.

The methodological weaknesses of this study were that the participants of the questionnaires might have different perceptions of the questions. To mitigate that, an open essay was added to some questions.

\section{REFERENCES}

Albakrawi, H. T. M. (2013). Needs analysis of the English language secondary hotel students in Jordan. International Journal of English Language Teaching, 1(1), 13-23.

Alsamadani, H. A. (2017). Needs analysis in ESP context: Saudi engineering students as a case study. Advances in Language and Literary Study, 8(6). 
Arifin, Z., Manalu, H.C.B., Deliana, R., \& Ariyanti, F. (2017, October 16-17). The implementation of curriculum 2013 in Vocational High School 4 Takengon. [Paper presentation]. The 2nd Annual International Seminar on Transformative Education and Educational Leadership (AISTEEL), Medan, Indonesia.

Astuti, P. (2009). A needs analysis in developing a writing curriculum for EFL education students: A case study at the department of English education.

Language Circle: Journal of Language and Literature, 4(1).

Bharati, D. A. L., \& Lestari, T. (2018). A need analysis in developing projectbased writing assessment module to stimulate students' critical thinking and creativity. UNNES International Conference on Research Innovation and Commercialization 2018, KnE Social Sciences, 130-138.

Bedoya, P.A., Valencia, L. M., \& Montoya, J.C. (2015). Students' needs analysis in EFL program for university professors. HOW, 22(2), 11-36.

Cahyati, S., Rahmijati, \& Rizkiani. (2014). Students' need analysis in the content of vocational high school English textbook. Didaktik, 8(1), 29-35.

Dewi, S.U. (2015). Syllabus of vocational high school based on ESP approach. Dinamika Ilmu, 15(2), 273-295.
Esthiningkrida, D. N., \& Munir, A. (2015). English language teaching challenge in state vocational high schools in Surabaya. Asian EFL Journal, 12(3), 145-163.

Hossain, J. (2013). ESP needs analysis for engineering students: A learner centred approach. Journal of Presidency University, 2(2), 16-26.

Hutchinson, T., \& Waters, A. (1991). English for specific purposes: A learning centered approach. Cambridge University Press.

Indrasari, N. (2016). ESP: A need analysis at the second semester of Physics education students of IAIN Raden Intan Lampung in the academic year of 2015/2016. English Education: Jurnal Tadris Bahasa Inggris, 9(1), 161-172.

Liao, T., Hsu, P.Y., Lee, C. L. \& Yang, K. F. (2017). English for specific purpose for EFL college interns in international tourism industry in Taiwan: Needs analysis and challenges. International Journal of Management and Applied Science, 3(7), 58-63.

Ronaldo, O. (2016). Teaching material for English subject in vocational high school. Proceedings of ISELT FBS Universitas Negeri Padang, 4(2), 170179.

Wahyono, E., \& Puspitasari, D. (2016). Students' need analysis of English reading skills for academic purposes. Proceeding ICTTE PKIP UNS 2015, 1(1), 1007-1014. 